\title{
Social Well-Being Scales: Validity and Reliability Evidence in the Portuguese Context
}

\author{
Ana Lages ${ }^{1}$, Eunice Magalhães ${ }^{2}$, Carla Antunes ${ }^{1} \&$ Célia Ferreira $^{1}$ \\ ${ }^{1}$ Universidade Lusófona do Porto, Portugal \\ 2 Instituto Universitário de Lisboa (ISCTE-IUL), Cis-IUL, Lisboa, Portugal
}

\begin{abstract}
This study aims to provide evidence of validity and reliability of the Social Well-being Scales in the Portuguese context. A cross-sectional study was developed with 322 adults $(M=30.45 ; S D=8.52)$ aged from 18 to 58 years old, mostly females (65.8\%). Confirmatory factor analysis revealed a good model fit considering the five-factor model consistent with the original theoretical proposal. Also, additional validity evidence was obtained with statistically significant associations being found between social well-being dimensions and satisfaction with life, depression and anxiety. Reliability data also showed adequate internal consistency of all well-being dimensions. This reliable and valid scale is useful to evaluate social well-being in adulthood in the Portuguese context, not only allowing a more comprehensive approach to the mental health research but also providing opportunities of assessment and intervention focused on a positive framework.
\end{abstract}

Keywords: Social Well-being Scales; Mental Health; Psychometrics; Adulthood.

Escalas de Bem-Estar Social: Evidências de validade e fidelidade no contexto português: Este estudo pretende providenciar evidências de validade e fidelidade das Escalas de Bem-Estar Social no contexto português. Foi desenvolvido um estudo transversal com 322 adultos $(M=30.45 ; \mathrm{SD}=8.52)$ com idades compreendidas entre os 18 e 58 anos, maioritariamente do sexo feminino (65.8\%). A Análise Fatorial Confirmatória revelou um bom ajustamento do modelo, considerando o modelo dos cinco fatores consistente com a proposta teórica original. Além disso, evidências de validade adicional foram obtidas através das associações estatisticamente significativas obtidas entre as dimensões de bem-estar social e a satisfação com a vida, depressão e ansiedade. Dados de fidelidade revelam adequada consistência interna para todas as dimensões de bem-estar. Esta escala é útil para avaliar o bem-estar social na idade adulta no contexto português, permitindo não só uma abordagem mais compreensiva da saúde mental, mas também providenciando oportunidades de avaliação e intervenção centradas numa perspetiva positiva.

\section{Palavras-chave: Escalas de Bem-Estar Social; Saúde Mental; Psicometria; Idade Adulta.}

The social dimension of well-being has been progressively stressed in the literature as an important contribution to understanding how an individual functions (Larson, 1993). It is not, in fact, only the significant others who are important; the feeling of social integration also has positive effects on psychological states: in terms of a sense of belonging and self-esteem (Kawachi \& Berkman, 2001). The positive influence of social integration and social roles is well-recognised in fostering self-esteem and preventing psychopathology (Berkman, Glass, Brissette, \& Seeman, 2000). Moreover, the World Health Organisation reinforces the importance of well-being indicators in terms of mental health, with its definition of health involving "a state of complete physical, mental and social well-being" (WHO, 2003). In this paper, we aim to provide evidence of the validity and reliability of a scale measuring social well-being in the Portuguese context, given that there is still a general lack of such measures.

Social well-being was defined by Keyes (1998) as "the appraisal of one's circumstance and functioning in society" (p. 122), specifying that living has a social nature and its challenges are viewed as criteria for achieving a better quality of life. As such, well-being, as derived from the social structure, is viewed by the author (Keyes, 1998) through a multidimensional model made up of five dimensions: a) Social integration is the perceived quality of an individual's relationship with their society and community. The individual feels integrated when they have something in common with the other members of their social context; b) Social acceptance involves the meaning the individual has constructed of their society, based on the characteristics and qualities of others. Individuals who demonstrate higher

${ }^{1}$ Morada para correspondência: Eunice Magalhães, Centro de Investigação e Intervenção Social, ISCTE-Instituto Universitário de Lisboa, Edf. ISCTE-IUL, Av. das Forças Armadas, 1649-026 Lisboa, Portugal. E-mail: Eunice_magalhaes@iscte-iul.pt 
levels of social acceptance rely on others, consider that others are able to be gentle, and believe that people can be diligent; c) Social contribution includes the individual's assessment of their social value: their self-efficacy and perceived responsibility, including the belief that they are an important member of the society; d) Social actualisation refers to the individual's evaluation of how the society develops and its trajectory, evolution and potential, which implies they believe that social growth is beneficial. Finally, e) Social coherence implies the individual's perception of the quality, organisation and functioning of the social world. Socially healthy individuals have a realistic view of the world and the desire to give meaning to life experiences (Keyes, 1998).

Consistent with the theoretical model, the author developed the Social Well-Being Scales (Keyes, 1998) in order to address the need of theoretically driven measurement tools. Several measures have been provided to assess individuals' perceptions of their social relationships or affiliation (e.g. The Social Support Questionnaire; Sarason, Levine, Basham, \& Sarason, 1983), as well as to evaluate anomie (e.g. The Perception of Anomie Scale; Teymoori et al., 2016) or alienation (The MOS alienation scale; Travis, 1993). However, even if these terms are used interchangeably in the literature, they are theoretically different. Social networks, more than synonyms of social integration, are conceptualised as a precursor of social engagement (Berkman et al., 2000). Neither are we interested in a traditional negative view of individual psychological adjustment (e.g. anomie). The aim here is rather to provide evidence of the validity and reliability of a scale based on a positive criteria of psychological functioning (Keyes, 1998). This measure effectively allows us to capture well-being, highlighting the importance of social structures to human development and the social context to the individual's well-being (Cicognani et al., 2008). There are benefits from social life (e.g. feeling connected to a community or society, as well as believing in the society's evolution may be associated with healthy life trajectories; Keyes, 1998) that reinforce the need to assess social well-being, more than merely evaluating individual aspects of well-being (e.g. selfacceptance, autonomy and purpose in life; Ryff, 1995; or satisfaction with one's life; Diener, Lucas, \& Oishi, 2002).

As far as we know, no other measure of social well-being has been developed from a solid theoretical model and been psychometrically tested. The scale was based on two studies: the first included 373 adults from a local town (Dane County, Wisconsin), while the second had 3032 adults from 48 North American States (Keyes, 1998). A confirmatory factor analysis was performed on both studies to evaluate the model fit of those five theoretical constructs, and adequate results were found on the goodness of fit model. Keyes (1998) has also provided evidence of convergent and discriminant validity, correlating the social well-being dimensions with measures of anomie, generativity, perceived social constraints, community involvement and neighbourhood quality, dysphoria, global well-being, physical health and optimism. Furthermore, reliability evidence was also achieved through the following values of internal consistency: a) Study 1 - Social Integration $(\alpha=.81)$, Social Acceptance $(\alpha=.77)$, Social Contribution $(\alpha=.75)$, Social Actualisation $(\alpha=.69)$ and Social Coherence $(\alpha=.57)$; b) Study 2 - Social Integration $(\alpha=.73)$, Social Acceptance $(\alpha=.41)$, Social Contribution $(\alpha=.66)$, Social Actualisation $(\alpha=$ $.64)$ and Social Coherence $(\alpha=.64)$ (Keyes, 1998). The author has suggested that some low internal consistencies could be derived from sampling variations and methodological specificities between the studies (one item was added to the social acceptance scale in the second study) (Keyes, 1998).

Even considering some low values of internal consistency, this measure seems the most appropriate for the gauging of Portuguese social well-being. It enables the assessment of multiple social dimensions of well-being outcomes (as postulated above), together with its international widespread use (Li, Yang, Ding, \& Kong, 2015; Keyes, 2006, 2007). Besides this, well-being has traditionally been conceptualised and measured from an intra-individual perspective (i.e. focused on depression, or perceived satisfaction with one's life), neglecting that individuals are socially constructed and integrated into a social structure (Keyes, 1998).

Although there has been a clear growth of research in Portugal focused on the adaptation and validation of measures on subjective (Simões, 1992) and psychological well-being (Novo, 2003), social well-being has not been considered. However, a proper understanding of mental health derives from the existence of valid and reliable measurement instruments, theoretically driven, and adapted to their application contexts. As such, we aimed to adapt and provide evidence of validity and reliability of the Social Well-being Scales in the Portuguese context. Specifically, we intended to explore a) validity evidence based on the internal structure (i.e. construct validity); b) validity evidence based on the relationship with other variables (i.e. convergent validity); and c) reliability evidence (i.e. internal consistency). 


\section{METHOD}

\section{Participants}

The participants in this study were 322 community adults, mostly female (65.8\%) and aged from 18 to 58 $\left(M_{\mathrm{age}}=30.45 ; S D=8.52\right)$. Most of these participants completed a higher education course (bachelor's degree: $37.1 \%$ and master's degree: $29.6 \%$ ), and were currently working (66\%). A large percentage of our participants were single (69.8\%), with only $25.2 \%$ married, $4.4 \%$ divorced and $0.6 \%$ widow.

\section{Measures}

Sociodemographic questionnaire. This questionnaire was used to describe our participants through a set of descriptive variables: their demographic attributes (e.g. sex, age and marital status) or academic and professional experience (e.g. the last academic degree completed and current professional status).

Social Well-Being Scales (Keyes, 1998). This scale consists of 33 items organised in five dimensions: Social Integration, Social Acceptance, Social Contribution, Social Actualisation and Social Coherence (Keyes, 1998). Through a Likert scale from 1 to 7 (from Strongly Disagree to Strongly Agree), participants are asked to rate their degree of social well-being. Higher scores mean that socially healthier people should not see society as unpleasant and see themselves as important members. They should care about and feel safe in the community, living a coherent life.

Brief Symptom Inventory (BSI; Derogatis, 1982). The Portuguese version of BSI was used in this study (Canavarro, 2007) in order to evaluate psychopathological symptoms. This inventory allows us to assess 9 dimensions (Somatisation, Obsessive-Compulsive, Interpersonal Sensitivity, Depression, Anxiety, Hostility, Phobic Anxiety, Paranoid Ideation and Psychoticism). In the present study, however, only the Anxiety Scale (6 items; $\alpha=.77$ ) and the Depression Scale (6 items; $\alpha=.73$ ) were evaluated (Canavarro, 2007). This option is due to national and international data suggesting that anxiety (3.6\% of the world population) and depression (4.4\%) are the most prevalent disorders (e.g. Carvalho, 2017). The items are answered using a Likert scale from 0 to 4 (from Never to Many Times). Higher scores mean great depression and anxiety symptomatology.

Satisfaction with Life Scale (SWLS; Diener et al., 1985). The Portuguese version of this scale was used (Simões, 1992) to assess the participants' life satisfaction. The scale consists of five items, positively written and answered in a Likert scale of 5 points (1 - Strongly Disagree to 5-Strongly Agree). Higher scores mean that our participants are extremely satisfied with their life. The internal consistency of the scale is good with a Cronbach's alpha of .87 (Simões, 1992).

\section{Procedures}

Translation and adaptation of the Social Well-Being Scales. Firstly, permission to adapt these scales was requested from the author. The translation and sociocultural adaptation were then carried out, following international recommendations (Behling \& Kenneth, 2000). A first translation was made by a researcher, which was then reviewed by two other independent researchers, fluent in the original (English) and target (Portuguese) language, as well as having particular expertise in the field. These two senior reviewers analysed and discussed the quality of the translation, taking into account semantic, linguistic and contextual/experiential equivalence. Semantic equivalence referred to the accordance in the meaning and sense of words; language equivalence considered colloquialisms and/or linguistic specificities, with non-linear translation; contextual/experiential equivalence pondered possible cultural specificities, ensuring the translation's suitability for the national context. For reasons of intelligibility and understanding, all translated items were reformulated and rewritten using the first-person singular. All other suggestions for improvement were incorporated, and the final translated version was backtranslated by a bilingual researcher. The original and back-translation was then discussed in order to analyse the comparability of the items. Most of the back-translated items corresponded integrally to their original items (with the exception of the grammatical person). In the remaining cases, it was concluded that the discrepancies preserved the central idea of the original item (e.g., Original item: "You think you have something valuable to give to the world"; back-translated item: "I think that I have something useful to offer the world").

Procedures of data collection. An online survey was carried out through institutional contacts (e.g. mailing lists of higher education institutions) and social networks (e.g. Facebook). The participation 
conditions were clarified, reinforcing the idea that participation was voluntary, anonymous and confidential.

Procedures of data analyses. Data analysis began with a sociodemographic description of our participants, followed by a descriptive analysis of all items from the scale, with 39 outliers being identified and removed. A total of 283 participants were considered for the validity and reliability analyses. Some items were reversed and a descriptive analysis was performed to evaluate the distribution normality (Skewness and Kurtosis). The low number of missing values led to their imputation (cf. table 1). The construct validity was tested using confirmatory factor analysis. Given that social well-being is a well-established construct in the literature, performing an Exploratory Factor Analysis (EFA) was considered unnecessary. Fit model criteria were: $\chi 2 / d f$ (chi square/freedom degrees) $<3$, The goodness of fit index (GFI) $>$ or equal to .90, the Comparative fit index (CFI) $>$ or equal to .95, the Parsimony Goodness-of-Fit Index (PGFI) > or equal to .60, the Root Mean Square Error of Approximation (RMSEA) < .08, and the Standardised Root Mean Square Residual (SRMR) <.10 (Hair, Black, Babin, \& Anderson, 2010; Hu \& Bentler, 1999; Schermelleh-Engel, Moosbrugger, \& Muller, 2003). Also, factor weights, individual reliability and modification indices were considered to obtain adequate measurement models.

The validity evidence based on the relationship with other variables (convergent validity) was tested by Pearson's correlation between all social well-being dimensions and life satisfaction, anxiety and depression. The internal consistency was analysed based on the Cronbach's Alpha for each dimension. Data analysis was performed through IBM SPSS ${ }^{\circledR}$ for Windows (Version 23.0) and IBM AMOS ${ }^{\circledR}$ for Windows (Version 20.0), with a $p$-value threshold of 0.05 .

\section{RESULTS}

\section{Descriptive Analysis}

The values of skewness (sk) and kurtosis (ku) of all items revealed that the assumption of normality was met (sk <3; ku <8) (Kline, 2005) (cf. table 1). The majority of these items (88\%) reveal that participants provided responses ranging from one to seven (except four items), which suggests that our items are relatively well-discriminated. Low percentages of missing values, moreover, reinforce the quality of data and the degree to which we can rely on these results.

Table 1. Descriptive statistics: Means, Standard deviation, Skewness and Kurtosis

\begin{tabular}{|c|c|c|c|c|c|c|c|c|c|}
\hline \multirow[b]{2}{*}{ Items } & \multirow{2}{*}{$\begin{array}{c}\text { \% } \\
\text { Missing } \\
\text { Values } \\
\end{array}$} & \multirow[b]{2}{*}{ Min } & \multirow[b]{2}{*}{ Max } & \multirow[b]{2}{*}{ Mean } & \multirow{2}{*}{$\begin{array}{c}\text { Std. } \\
\text { deviation }\end{array}$} & \multicolumn{2}{|c|}{ Skewness } & \multicolumn{2}{|c|}{ Kurtosis } \\
\hline & & & & & & Statistic & $\begin{array}{c}\text { Std. } \\
\text { Error }\end{array}$ & Statistic & $\begin{array}{c}\text { Std. } \\
\text { Error }\end{array}$ \\
\hline 1 & 1 & 1 & 7 & 5.27 & 1.73 & -0.67 & 0.15 & -0.67 & 0.29 \\
\hline 2 & 0 & 1 & 7 & 4.39 & 1.64 & -0.06 & 0.15 & -1.03 & 0.29 \\
\hline 3 & 0 & 1 & 7 & 4.77 & 1.32 & -0.66 & 0.15 & 0.43 & 0.29 \\
\hline 4 & 0 & 1 & 7 & 4.38 & 1.74 & -0.04 & 0.15 & -1.08 & 0.29 \\
\hline 5 & 1 & 1 & 7 & 5.26 & 1.53 & -0.63 & 0.15 & -0.43 & 0.29 \\
\hline 6 & 4 & 1 & 7 & 4.44 & 1.24 & -0.40 & 0.15 & 0.19 & 0.29 \\
\hline 7 & 1 & 1 & 7 & 4.23 & 1.30 & -0.44 & 0.15 & -0.01 & 0.29 \\
\hline 8 & 2 & 2 & 7 & 5.19 & 1.08 & -0.41 & 0.15 & 0.13 & 0.29 \\
\hline 9 & 1 & 1 & 7 & 4.10 & 1.61 & 0.05 & 0.15 & -0.65 & 0.29 \\
\hline 10 & 0 & 2 & 7 & 5.86 & 1.33 & -1.04 & 0.15 & 0.11 & 0.29 \\
\hline 11 & 0 & 1 & 7 & 4.39 & 1.28 & -0.40 & 0.15 & -0.04 & 0.29 \\
\hline 12 & 0 & 1 & 7 & 3.39 & 1.21 & 0.34 & 0.15 & -0.09 & 0.29 \\
\hline 13 & 0 & 1 & 7 & 4.76 & 1.56 & -0.30 & 0.15 & -0.73 & 0.29 \\
\hline 14 & 1 & 1 & 7 & 4.14 & 1.62 & -0.12 & 0.15 & -0.78 & 0.29 \\
\hline 15 & 2 & 1 & 7 & 4.85 & 1.55 & -0.25 & 0.15 & -0.73 & 0.29 \\
\hline 16 & 1 & 1 & 7 & 4.77 & 1.28 & -0.54 & 0.15 & 0.44 & 0.29 \\
\hline 17 & 0 & 1 & 7 & 4.37 & 1.62 & 0.01 & 0.15 & -1.08 & 0.29 \\
\hline 18 & 3 & 1 & 7 & 4.85 & 1.55 & -0.22 & 0.15 & -0.90 & 0.29 \\
\hline
\end{tabular}




\begin{tabular}{|c|c|c|c|c|c|c|c|c|c|}
\hline \multirow[b]{2}{*}{ Items } & \multirow{2}{*}{$\begin{array}{c}\text { \% } \\
\text { Missing } \\
\text { Values }\end{array}$} & \multirow[b]{2}{*}{ Min } & \multirow[b]{2}{*}{ Max } & \multirow[b]{2}{*}{ Mean } & \multirow{2}{*}{$\begin{array}{c}\text { Std. } \\
\text { deviation }\end{array}$} & \multicolumn{2}{|c|}{ Skewness } & \multicolumn{2}{|c|}{ Kurtosis } \\
\hline & & & & & & Statistic & $\begin{array}{l}\text { Std. } \\
\text { Error }\end{array}$ & Statistic & $\begin{array}{c}\text { Std. } \\
\text { Error }\end{array}$ \\
\hline 19 & 1 & 1 & 7 & 4.20 & 1.52 & -0.27 & 0.15 & -0.55 & 0.29 \\
\hline 20 & 1 & 1 & 7 & 5.22 & 1.46 & -0.59 & 0.15 & -0.22 & 0.29 \\
\hline 21 & 1 & 1 & 7 & 4.09 & 1.39 & -0.35 & 0.15 & -0.16 & 0.29 \\
\hline 22 & 1 & 1 & 7 & 3.74 & 1.56 & 0.11 & 0.15 & -0.85 & 0.29 \\
\hline 23 & 0 & 1 & 7 & 4.94 & 1.38 & -0.93 & 0.15 & 1.00 & 0.29 \\
\hline 24 & 0 & 1 & 7 & 4.16 & 1.37 & -0.48 & 0.15 & -0.09 & 0.29 \\
\hline 25 & 2 & 2 & 7 & 5.56 & 1.04 & -0.59 & 0.15 & 0.08 & 0.29 \\
\hline 26 & 2 & 1 & 7 & 4.95 & 1.48 & -0.45 & 0.15 & -0.43 & 0.29 \\
\hline 27 & 0 & 1 & 7 & 3.49 & 1.51 & 0.43 & 0.15 & -0.56 & 0.29 \\
\hline 28 & 2 & 2 & 7 & 5.62 & 1.36 & -0.77 & 0.15 & -0.32 & 0.29 \\
\hline 29 & 1 & 1 & 7 & 4.98 & 1.66 & -0.52 & 0.15 & -0.62 & 0.29 \\
\hline 30 & 3 & 1 & 7 & 4.03 & 1.50 & 0.00 & 0.15 & -0.61 & 0.29 \\
\hline 31 & 2 & 1 & 7 & 4.67 & 1.27 & -0.78 & 0.15 & 0.77 & 0.29 \\
\hline 32 & 0 & 1 & 7 & 3.97 & 1.46 & -0.40 & 0.15 & -0.56 & 0.29 \\
\hline 33 & 0 & 1 & 7 & 3.34 & 1.42 & -0.08 & 0.15 & -0.62 & 0.29 \\
\hline
\end{tabular}

Validity Evidence Based on the Internal Structure

The confirmatory factor analysis was performed considering the original theoretical and measurement model (Model 1), composed of 33 items. However, this first model showed poor fit indices (cf. table 2).

Table 2. Fit indices obtained from the confirmatory factor analysis

\begin{tabular}{lccccccc}
\hline Modelos & \multirow{2}{*}{$\chi 2(\mathrm{df})$} & $\chi 2 / \mathrm{df}$ & GFI & CFI & $\begin{array}{c}\text { RMSEA } \\
{[90 \% \mathrm{CI}]}\end{array}$ & SRMR & PGFI \\
\hline Model 1 & $1511.051(485)$ & $3.12^{* * *}$ & .69 & .72 & $.087[.082 ; .092]$ & .097 & .60 \\
Model 2 & $933.145(265)$ & $3.52^{* * *}$ & .75 & .78 & $.095[.088 ; .101]$ & .097 & .62 \\
Model 3 & $309.090(142)$ & $2.18^{* * *}$ & .90 & .92 & $.065[.055 ; .074]$ & .052 & .67 \\
\hline
\end{tabular}

Note. ${ }^{* * *} \mathrm{p}<.001$

In order to understand how the fit model could be improved, factor weights and individual reliability were analysed for all items. We found that eight items showed factor weights $<0.5$ (cf. table 3 ; bold items) and values of $R^{2}<.25$ (cf. table 4).

Table 3. Factor weights of all items for each dimension

\begin{tabular}{rrrr}
\hline Item & & Dimension & Factor Weight \\
\hline $\mathbf{1}$ & $<---$ & Social Integration &. $\mathbf{4 8}$ \\
6 & $<---$ & Social Integration & .59 \\
11 & $<---$ & Social Integration & .64 \\
16 & $<---$ & Social Integration & .69 \\
21 & $<---$ & Social Integration & .69 \\
26 & $<---$ & Social Integration & .60 \\
31 & $<---$ & Social Integration & .64 \\
2 & $<---$ & Social Acceptance & .80 \\
7 & $<---$ & Social Acceptance & .56 \\
$\mathbf{1 2}$ & $<---$ & Social Acceptance & .34 \\
17 & $<---$ & Social Acceptance & .89 \\
22 & $<---$ & Social Acceptance & .68 \\
27 & $<---$ & Social Acceptance & .73 \\
32 & $<---$ & Social Acceptance & .53 \\
\hline
\end{tabular}




\begin{tabular}{rrrrr}
\hline Item & & Dimension & Factor Weight \\
\hline $\mathbf{3}$ & $<--$ & Social Contribution & .39 \\
13 & $<---$ & Social Contribution & .43 \\
18 & $<---$ & Social Contribution & .52 \\
$\mathbf{2 3}$ & $<---$ & Social Contribution & Social Contribution & .58 \\
28 & $<---$ & Social Contribution & .49 \\
4 & $<---$ & Social Actualization & .75 \\
9 & $<---$ & Social Actualization & .72 \\
14 & $<---$ & Social Actualization & .69 \\
19 & $<---$ & Social Actualization & .53 \\
24 & $<---$ & Social Actualization & .68 \\
29 & $<---$ & Social Actualization & .60 \\
33 & $<---$ & Social Actualization & .61 \\
5 & $<---$ & Social Coherence & .63 \\
$\mathbf{1 0}$ & $<---$ & Social Coherence & .63 \\
15 & $<---$ & Social Coherence & .39 \\
20 & $<---$ & Social Coherence & .73 \\
$\mathbf{2 5}$ & $<---$ & Social Coherence & .58 \\
$\mathbf{3 0}$ & $<---$ & Social Coherence &. $\mathbf{2 7}$ \\
& & & .20 \\
\hline
\end{tabular}

Table 4. Individual reliability of all items

\begin{tabular}{cccccc}
\hline Item & $\boldsymbol{R}^{\mathbf{2}}$ & Item & $\boldsymbol{R}^{\mathbf{2}}$ & Item & $\boldsymbol{R}^{\mathbf{2}}$ \\
\hline $\mathbf{3 0}$ & $\mathbf{. 0 4}$ & 9 & .48 & 17 & .80 \\
$\mathbf{2 5}$ & $\mathbf{. 0 7}$ & 4 & .52 & $\mathbf{1 2}$ & $\mathbf{. 1 2}$ \\
20 & .33 & 28 & .56 & 7 & .31 \\
15 & .53 & $\mathbf{2 3}$ &. $\mathbf{2 4}$ & 2 & .64 \\
$\mathbf{1 0}$ & $\mathbf{. 1 5}$ & 18 & .33 & 31 & .41 \\
5 & .39 & 13 & .27 & 26 & .35 \\
33 & .40 & $\mathbf{8}$ & $\mathbf{. 1 8}$ & 21 & .48 \\
29 & .37 & $\mathbf{3}$ &. $\mathbf{1 5}$ & 16 & .48 \\
24 & .35 & 27 & .28 & 11 & .41 \\
19 & .46 & 22 & .53 & 6 & .34 \\
14 & .28 & .46 & $\mathbf{1}$ & .23 \\
\hline
\end{tabular}

These items were removed from the analysis, as suggested in the literature (Maroco, 2010), and a second model was tested. This model also showed weak fit indices (Model 2; cf. table 2) and, therefore, an analysis of the modification indices was carried out. Based on this analysis, five items were removed ( 7 , $19,21,32,33)$, which had high modification indices with items or dimensions representing a different theoretical factor (Maroco, 2010). After the removal of these items, we found that item 24 showed a factor weight $<0.5$ (Maroco, 2010), and it was also removed from the model in accordance with our previous criteria. Finally, the new model showed an adequate model fit (Model 3; cf. table 2), including the 5 original theoretical dimensions and containing 19 items (cf. figure 1; see the Portuguese items in the appendix). 


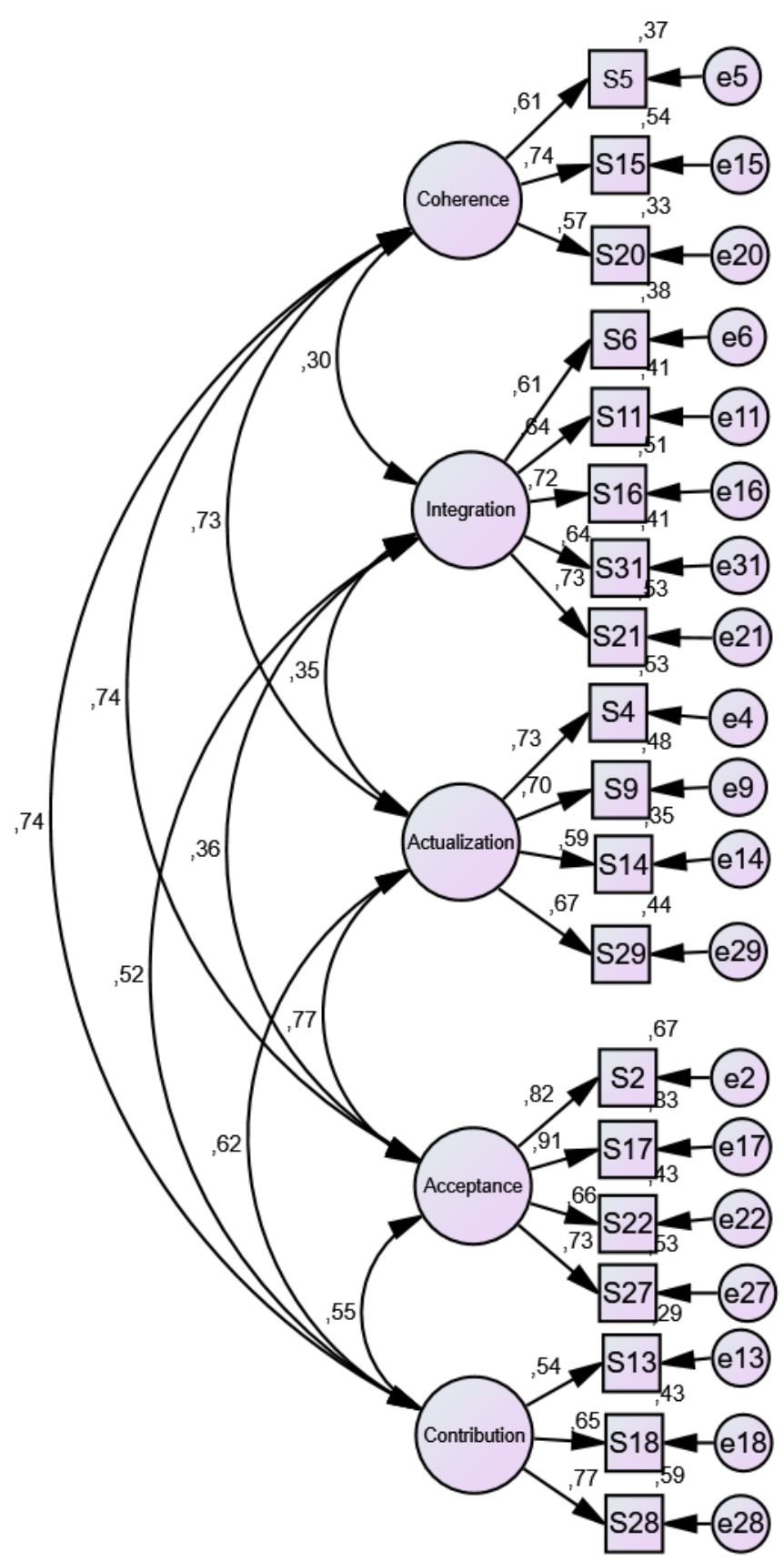

Figure 1. Final Model from the confirmatory factor analysis (19 items)

Validity Evidence Based on the Relationship between Social Well-Being and Life Satisfaction, Depression and Anxiety

Statistically, significant correlations were found between all the social well-being dimensions. Low correlations $(<.30)$ were found between Social Integration and Social Acceptance, Social Contribution and Social Actualisation. Furthermore, the results revealed a positive correlation between social well-being dimensions and satisfaction with life, while a negative correlation was obtained with depression and anxiety. Concomitantly, there were positive correlations between all the dimensions of social well-being. Higher levels of social well-being are, thus, associated with greater life satisfaction and with lower symptoms of anxiety and depression (cf. table 5). 
Table 5. The relationship between Social well-being, Satisfaction with life, and Psychopathology.

\begin{tabular}{lccccccc}
\hline & $\mathbf{2}$ & $\mathbf{3}$ & $\mathbf{4}$ & $\mathbf{5}$ & $\mathbf{6}$ & $\mathbf{7}$ & Anxiety \\
\hline 1. Social Acceptance & $.667^{* * *}$ & $.299^{* * *}$ & $.428^{* * *}$ & $.578^{* * *}$ & $.358^{* * *}$ & $-.445^{* * *}$ & $-.364^{* * *}$ \\
2. Social Actualization & 1 & $.259^{* * *}$ & $.439^{* * *}$ & $.531^{* * *}$ & $.366^{* * *}$ & $-.413^{* * *}$ & $-.358^{* * *}$ \\
3. Social Integration & & 1 & $.386^{* * *}$ & $.213^{* * *}$ & $.368^{* * *}$ & $-.327^{* * *}$ & $-.233^{* * *}$ \\
4. Social Contribution & & & 1 & $.495^{* * *}$ & $.235^{* * *}$ & $-.441^{* * *}$ & $-.342^{* * *}$ \\
5. Social Coherence & & & & 1 & $.260^{* * *}$ & $-.416^{* * *}$ & $-.394^{* * *}$ \\
6.Satisfation with life & & & & & 1 & $-.546^{* * *}$ & $-.391^{* * *}$ \\
7.Depression & & & & & 1 & $.813^{* * *}$ \\
\hline
\end{tabular}

Note. ${ }^{* * *} \mathrm{p}<.001$

\section{Reliability}

Cronbach's alpha coefficients were appropriate considering all social well-being dimensions: Social Acceptance $(\alpha=.86)$, Social Actualisation $(\alpha=.76)$, Social Integration $(\alpha=.80)$, Social Contribution $(\alpha=$ $.70)$ and Social Coherence $(\alpha=.67)$.

\section{DISCUSSION}

The present study aimed to address the need of a valid and reliable scale to evaluate social well-being, taking into account the importance of this domain for the functioning of an individual (Berkman et al., 2000; Kawachi \& Berkman, 2001; Keyes, 1998, 2005). The validity evidence based on the internal structure (i.e. construct validity) was assessed through a confirmatory factor analysis, and the results revealed that the original structure showed poor fit indices. Based on the literature suggestions (Maroco, 2010), a set of analytical strategies were implemented, which resulted in a final model composed of 19 items and with adequate fit indices. Even considering that the CFI was not greater than .95 (SchermellehEngel et al., 2003), it can be considered acceptable since it was above .90 and close to .95 (Bentler, 1990). Even considering these results, the decision about not performing an EFA before the CFA was taken, considering that the construct of social well-being is theoretically well-established (Keyes, 1998). In that an equivalent factorial structure with the Portuguese sample was found, proving validity and reliability, these methodological options remain appropriate.

The validity evidence, based on the relationship with other variables (i.e. convergent validity), reinforced the soundness of this scale in the Portuguese context given that all dimensions of social wellbeing correlated positively with life satisfaction, and were consistent with previous evidence (Li et al., 2015). Specifically, lower correlations were found with social contribution and social coherence, which may suggest that satisfaction with life is more related to individuals' perceptions of the quality of their relationship with others/society (social integration), the perceived qualities of other people (social acceptance) and the society's evolution beliefs (social actualisation). On the other hand, subjective wellbeing seems to be less related to individuals' beliefs about their social value (i.e. they believe that they are vital to society), as well as their understanding about what is happening in the society/world (Keyes, 1998). As such, we hypothesise that individuals may judge their standards about circumstances of life (Pavot \& Diener, 1993) more in terms of their relationships and integration than in terms of their role in the society.

Moreover, significant and negative correlations were found among all dimensions of social wellbeing and depressive and anxious symptoms, which is also theoretically and empirically consistent with previous data (Berkman et al., 2000; Keyes, 2005). Specifically, social integration revealed a lower correlation coefficient than other dimensions of social well-being, with both depression and anxiety. As such, contrarily to the association between social integration and life satisfaction, it seems that social integration appears less related to depressive or anxious symptoms. Furthermore, social well-being subscales seem to be more strongly associated with depression than with anxiety, suggesting that feeling sad, a negative mood, loss of energy and feelings of guilt (depressive symptoms) could be more associated with lower levels of social well-being than being significantly nervous or worried.

Finally, reliability evidence was achieved with Cronbach Alpha coefficients being around or above .70 for all dimensions. Comparing this data with the original one, we found higher values of reliability for some dimensions (e.g. Social Acceptance, Social Actualisation and Social Coherence) (Keyes, 1998), which suggests that, despite the need to reduce the number of items in our final model, it does not seem to have weakened the internal consistency of these scales. More than the number of items per dimension, it seems to be the quality of those items that matters in measuring social well-being, with our results reinforcing the conceptual equivalence of the social well-being structure. Actually, considering that 
Cronbach Alpha is sensitive to the number of questions, our results may suggest that a smaller number of questions reduced redundancy, but did not undermine the internal consistency of well-being subscales.

Even considering the theoretical and empirical relevance of these results, it is important to identify some limitations. First, this study includes a non-random sample. In addition, data was only collected online, and it would be important to include other participants than those who have access to online platforms in order to have a more diverse and representative adult sample. Nevertheless, online data collection also has some advantages, such as low costs, less time consuming and flexibility for participants answering the instruments in their own time and place. Finally, additional types of validity should be tested in the future, namely with longitudinal designs enabling predictive validity evidence to be obtained. Despite these limitations, our results may significantly contribute to the development of this area, involving a range of important implications for research and practice.

This study, in fact, provided significant evidence about the validity and reliability of this scale, which is an important step for future studies on social well-being, and particularly when considering a holistic approach to mental health during adulthood. Having a scale that reveals adequate psychometric evidence may allow for the testing of some theoretical assumptions disseminated in the literature; namely, that "the presence of mental health is presumed to be the summum bonum of personal functioning and social value" (Keyes, 2005, p. 539). In the Portuguese context, therefore, if we have psychometrically sound scales on personal functioning (i.e. subjective and psychological well-being), social well-being caused some research problems. Moreover, the original five dimension measurement model was replicated in our study. This allowed for the development of cross-cultural studies, as well as the international comparability of findings.

Considering the intervention and professional practices, this study has a set of important implications. First of all, psychological assessment benefits from the availability of a scale focused on social dimensions of well-being, going further than the traditional focus on psychopathology measurement or the simple assessment of subjective and psychological well-being. Considering the widely discussed importance of social context in human development, if professionals have the opportunity to collect that information, then they will be able to formulate more accurate clinical hypotheses about adult functioning. Second, this improvement in the quality of psychological assessment has implications for intervention effectiveness in mental health, as well as for other health outcomes. If we are able to develop an intervention focused on the promotion of social well-being and not merely on symptom reduction, we are also promoting other positive outcomes in individual development. There is evidence that when comparing completely mentally healthy individuals (high levels of well-being and low psychopathology) with those having low psychopathology but also low well-being, it is the latter group that tend to show more physical health problems (Keyes, 2007). Specifically, the author suggests that "it is noteworthy that mental health status was a significant predictor of chronic physical conditions even after adjustment for the usual sociodemographic variables as well as body mass index, diabetes status, smoking status, and level of physical exercise" (Keyes, 2007, p.101). On the other hand, mental health professionals must be aware of the importance of reducing social isolation, promoting social integration and contributing to higher levels of social well-being, which has positive implications for the sense of belonging and security and also for self-esteem (Kawachi \& Berkman, 2001).

In sum, there are a set of reasons to invest in well-being. Not only do higher levels of well-being tend to be associated with positive physical health outcomes and longevity, but they are also related to successful functioning at the workplace or in an academic setting. It is less expensive to promote wellbeing than reduce mental illness (Howell, Coffey, Fosco, Kracke, Nelson, Rothman \& Grych, 2016); and, for that reason, psychometrically sound instruments must be available.

\section{REFERENCES}

Behling, O. \& Kenneth, S. L. (2000). Translating questionnaires and other research instruments: Problems and solutions. Thousand Oaks CA: SAGE Publications, Inc.

Bentler, P. M. (1990). Comparative fit indexes in structural models. Psychological Bulletin, 107(2), 238246. http://dx.doi.org/10.1037/0033-2909.107.2.238

Berkman, L. F., Glass, T., Brissette, I., \& Seeman, T. E. (2000). From social integration to health: Durkheim in the new Millennium. Social Science \& Medicine, 51(6), 843-857. https://doi.org/10.1016/S02779536(00)00065-4

Canavarro, M. C. (2007). Inventário de Sintomas Psicopatológicos (BSI). Uma revisão crítica dos estudos realizados em Portugal. In M. R. Simões, C. Machado, M. M. Gonçalves, \& L. S. Almeida (Coords.), Avaliação psicológica: Instrumentos validados para a população portuguesa (Vol. III) (pp. 305-331). Coimbra: Quarteto. 
Carvalho, A. (2017). Depressão e outras perturbações mentais comuns. Enquadramento global e nacional e referência de recurso em casos emergentes. Lisboa: Direção-Geral da Saúde.

Cicognani, E., Pirini, C., Keyes, C., Joshanloo, M., Rostami, R., \& Nosratabadi, M. (2008). Social participation, sense of community and social well-being: A study on American, Italian and Iranian university students. Social Indicator Research, 89(1), 97-112. http://dx.doi.org/10.1007/s11205-007-9222-3

Diener, E., Lucas, R. E., \& Oishi, S. (2002). Subjective well-being. The science of happiness and life satisfaction. In C. R. Snyder \& S. J. Lopez (Eds.), Handbook of Positive Psychology (pp. 63-73). London: Oxford University Press.

Hair, J. F., Black, W. C., Babin, B. J., \& Anderson, R. E. (2010). Multivariate data analysis (7th ed.). Englewood Cliffs: Prentice Hall:

Howell, K. H., Coffey, J. K., Fosco, G. M., Kracke, K., Nelson, S. K., Rothman, E., F., \& Grych, J. H. (2016). Seven reasons to invest in well-being. Psychology of Violence, 6(1), 8-14. http://dx.doi.org/10.1037/vio0000019

Hu, L. \& Bentler, P. (1999). Cutoff criteria for fit indexes in covariance structure analysis: Conventional criteria versus new alternatives. Structural Equation Modelling, 6(1), 1-55. http://dx.doi.org/10.1080/10705519909540118

Kawachi, I. \& Berkman, L. F. (2001). Social ties and mental health. Journal of Urban Health, 78(3), 458-467. http://dx.doi.org/10.1093/jurban/78.3.458

Keyes, C. L. M. (1998). Social well-being. Social Psychology Quarterly, 61(2), 121-140. http://dx.doi.org/10.2307/2787065

Keyes, C. L. M. (2005). Mental illness and/or mental health? Investigating axioms of the complete state model of health. Journal of Consulting and Clinical Psychology, 73(3), 539-548. http://dx.doi.org/10.1037/0022-006X.73.3.539

Keyes, C. L. M. (2006). Subjective well-being in mental health and human development research worldwide: An introduction. Social Indicators Research, 77, 1-10. http://dx.doi.org/10.1007/s11205-005-5550-3

Keyes, C. L. M. (2007). Promoting and protecting mental health as flourishing. A complementary strategy for improving national mental health. American Psychologist, 62(2), 95-108. http://dx.doi.org/10.1037/0003-066X.62.2.95

Kline, R. (2005). Principles and practice of structural equations modeling (2nd ed.). London: Guilford.

Larson, J. S. (1993). The measurement of social well-being. Social Indicators Research, 28(3), 285-296. http://dx.doi.org/10.1007/BF01079022

Li, M., Yang, D., Ding, C., \& Kong, F. (2015). Validation of the social well-being scale in a Chinese sample and invariance across gender.Social Indicators Research,121(2), 607-618. http://dx.doi.org/10.1007/s11205-014-0639-1

Maroco, J. (2010). Análise de Equações Estruturais: Fundamentos Técnicos, Software \& Aplicações. Pero Pinheiro: ReportNumber.

Novo, R. F. (2003). Para além da eudaimonia. O bem-estar psicológico em mulheres na idade adulta avançada. Lisboa: Fundação Calouste Gulbenkian. Fundação para a Ciência e Tecnologia.

Pavot, W. \& Diener, E. (1993). Review of the Satisfaction With Life Scale. Psychological Assessment, 5(2), 164-172. http://dx.doi.org/10.1037/1040-3590.5.2.164

Ryff, C. D. (1995). Psychological well-being in adult life. Current Directions in Psychological Science, 4(4), 99-104. http://dx.doi.org/10.1111/1467-8721.ep10772395

Sarason, I. G., Levine, H. M., Basham, R. B., \& Sarason, B. R. (1983). Assessing social support: The Social Support Questionnaire. Journal of Personality and Social Psychology, 44(1), 127-139. http://dx.doi.org/10.1037/0022-3514.44.1.127

Schermelleh-Engel, K., Moosbrugger, H., \& Muller, H. (2003). Evaluating the fit of structural equation models: Tests of significance and descriptive goodness-of-fit measures. Methods of Psychological Research Online, 8(2), 23-74.

Simões, A. (1992). Ulterior validação de uma Escala de Satisfação com a Vida (SWLS). Revista Portuguesa de Pedagogia, XXVI(3), 503-515.

Teymoori, A., Jetten, J., Bastian, B., Ariyanto, A., Autin, F., Ayub, N., et al. (2016). Revisiting the measurement of anomie. PLOS ONE, 11(7), 1-27. http://dx.doi.org/10.1371/journal.pone.0158370.

Travis, R. (1993). The MOS Alienation Scale: An alternative to Srole's Anomia Scale. Social Indicators Research, 28(1), 71-91.

World Health Organization [WHO] (2003). Investing in Mental Health. Geneva: WHO. 
Lages, Magalhães, Antunes \& Ferreira

Historial do artigo

Recebido 25/07/2017

Aceite $\quad 09 / 08 / 2018$

Publicado 12/2018 


\section{APPENDIX}

\section{Social Well-Being Scales - Portuguese Items (Original Items)}

\section{Social Integration}

Sinto que sou uma parte importante da minha comunidade (You feel like you're an important part of your community)

Se eu tivesse algo a dizer, considero que as pessoas da minha comunidade me ouviriam (If you had something to say, you believe people in your community would listen to you)

Sinto-me próximo de outras pessoas na minha comunidade (You feel close to other people in your community)

Vejo a minha comunidade como uma fonte de suporte (You see your community as a source of comfort) Considero que as outras pessoas na sociedade me valorizam como pessoa (You believe other people in society value you as a person)

\section{Social Acceptance}

Penso que as outras pessoas não são fiáveis* (You think that other people are unreliable) Sinto que as pessoas não são de confiança* (You feel that people are not trustworthy) Penso que as pessoas vivem apenas para si próprias* (You think that people live only for themselves) Considero que, nos dias de hoje, as pessoas são cada vez mais desonestas* (You believe that people are more and more dishonest these days)

\section{Social Contribution}

As minhas atividades diárias não são uma mais-valia para a minha comunidade* (Your daily activities do not produce anything worthwhile for your community)

Não tenho o tempo ou a energia para dar algo à minha comunidade* (You don't have the time or energy to give anything to your community)

Sinto que não tenho nada de importante a contribuir para a sociedade* (You feel you have nothing important to contribute to society)

\section{Social Actualization}

Considero que a sociedade parou de progredir* (You believe that society has stopped making progress) Para pessoas como eu, a sociedade não tem melhorado* (Society isn't improving for people like you) Penso que as entidades sociais (e.g., legais e governamentais) não melhoram a minha vida* (You don't think social institutions like law and government make your life better)

Para mim não existe verdadeiro progresso social* (For you there's no such thing as social progress)

\section{Social Coherence}

O mundo é demasiado complexo para mim* (The world is too complex for you) Eu não consigo dar sentido ao que acontece no mundo* (You cannot make sense of what's going on in the world)

A maioria das culturas é tão estranha que não as consigo perceber* (Most cultures are so strange that you cannot understand them)

*Items reversed. 